\title{
Peran Orang Tua dalam Meningkatkan Kesadaran Ibadah Shalat Anak
}

Ade Amarta Yolanda ${ }^{1}$, Wirdati ${ }^{2}$

amarthaa06@gmail.com¹, wirdati@fis.unp.ac.id ${ }^{2}$

Universitas Negeri Padang1,2

\begin{tabular}{|c|c|}
\hline ARTICLE INFO & ABSTRACT \\
\hline Article history: & \multirow{8}{*}{$\begin{array}{l}\text { Penelitian ini dilakukan untuk mengetahui peran } \\
\text { orang tua dalam meningkatkan kesadaran ibadah shalat } \\
\text { anak di Jorong Aceh Baru. Penelitian ini menggunakan } \\
\text { metode kualitatif deskriptif dengan pendekatan kualitatif. } \\
\text { Sumber data diambil melalui wawancara lansung yaitu } \\
\text { dengan para orang tua yang mimiliki anak berumur kisaran } \\
6-12 \text { tahun. Untuk memperkuat data penulis juga } \\
\text { mengambil data melalui observasi dan dokumentasi. } \\
\text { Seluruh data wawancara dianalisis dengan cara reduksi } \\
\text { data, penyajian data, dan penarikan kesimpulan. Secara } \\
\text { keseluruhan hasil keseluruhan mendapati bahwa (1) orang } \\
\text { tua mendidik anak dengan cara memasukan anak ke } \\
\text { MDA/TPA, mengulang kembali apa yang dipelajari anak, } \\
\text { menceritakan pahala bagi orang yang melaksanakan shalat, } \\
\text { mengajak anak untuk melaksanakan shalat di masjid dan di } \\
\text { rumah, memberikan pengarahan dan pemahaman pada } \\
\text { anak tentang pentingnya beribadah. (2) orang tua sebagai } \\
\text { motivator dilakukan dengan cara memberikan hadiah } \\
\text { kepada anak jika melaksanakan shalat, memberikan pujian } \\
\text { kepada anak, memberikan fasilitas beribadah yang lengkap, } \\
\text { menciptakan keluarga yang harmonis. (3) orang tua } \\
\text { sebagai pengawas dilakukan dengan cara selalu bertanya } \\
\text { kepada anak apakah sudah melaksanakan shalat, selalu } \\
\text { mengingatkan untuk melaksanakan shalat tepat waktu, } \\
\text { mengawasi pergaulan anak, selalu bertanya kepada guru } \\
\text { bagaimana ibadah si anak, memantau dan menemani anak } \\
\text { saat menonton televisi dan bermain handphone. }\end{array}$} \\
\hline Received, 24 August 2021 & \\
\hline Revised, 28 August 2021 & \\
\hline & \\
\hline & \\
\hline Kesadaran, Ibadah Shalat & \\
\hline $\begin{array}{l}\text { Clonflict of Interest: } \\
\text { None }\end{array}$ & \\
\hline $\begin{array}{l}\text { Funding: } \\
\text { None }\end{array}$ & \\
\hline
\end{tabular}

Corresponding Author: Ade Amarta Yolanda, Department Islamic Education Faculty of Social Science Universitas Negeri Padang, Indonesia, Email: amarthaa06@gmail.com Phone: $+6283188363042$

\section{Pendahuluan}

Shalat adalah tiang agama. Shalat adalah ibadah pertama yang akan diperhitungkan di akhirat nanti. Shalat dalam islam mempunyai kedudukan yang spesial dibandingkan ibadah lain-lainnya. Shalat merupakan kewajiban pertama bagi umat islam. Sebagai sebuah kewajiban, perintah untuk melaksanakan tidak boleh ditinggalkan. Sebagaimana dijelaskan dalam firman Allah SWT:

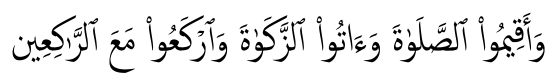


Ade Amarta Yolanda dan Wirdati: Peran Orang Tua dalam Meningkatkan Kesadaran...

Artinya: Dan dirikanlah shalat, tunaikanlah zakat dan ruku'lah beserta orang-orang yang ruku'. (al- Baqarah:43).

Ayat di atas memerintahkan kita untuk melaksanakan shalat. Sholat merupakan salah satu rukun Islam setelah syahadatain. Dan amal yang paling utama setelah syahadatain. Barang siapa menolak kewajibannya karena bodoh maka ia harus dipahamkan tentang wajibnya sholat tersebut, barang siapa tidak meyakini tentang wajibnya shalat (menentang) maka dia telah kafir (Ridwan Hasan, 2009, p. 61). Barangsiapa yang meninggalkan sholat karena menggampangkan atau malas, maka wajib baginya untuk bertaubat kepada Allah. Rasulullah bersabda:

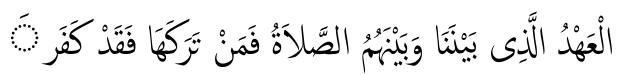

Artinya: "Perjanjian antara kami dan mereka (orang kafir) adalah shalat. Barang siapa meninggalkannya maka dia telah kafir." (HR. Ahmad, Tirmizi, An Nasa'i, Ibnu Majah)

Peranan orang tua paling utama yaitu menanamkan nilai agama. Untuk menanamkan nilai agama kepada anak tidaklah mudah, membutuhkan waktu dan kesabaran yang tinggi, tidak hanya sesekali dalam menanamkan nilai agama pada anak tetapi harus secara terus menerus dan tidak terputus. Karena seorang anak diciptakan dalam keadaan siap menerima kebaikan dan keburukan (Jamaal 'Abdul Rahman, 2005, p. 23). Macam-macam peran orang tua terhadap anak terdiri dari :

1. Sebagai pendidik yaitu mendidik merupakan hal yang pertama yang harus diterapkan kepada anak, sebelum anak mengenal dunia pendidikan orang tua mempunyai kewajiban untuk mendidik anaknya terlebih dahulu.

2. Sebagai pemberi motivasi atau pendorong yaitu orang tua memberikan motivasi kepada anaknya agar anak menjadi semangat dan percaya diri dalam menghadapi setiap masalah dalam hidupnya.

3. Sebagai pengawas yaitu kewajiban orang untuk melihat dan mengawasi segala aktifitas anaknya (Ndibo \& Baru, 2020, pp. 81-82).

Peranan orang tua dalam mendidik anak dilakukan dengan cara pembiasaan, nasihat dan cerita, keteladanan, pemeliharaan, partisipasi, disiplin dan memotivasi. Orang tua memberikan bimbingan kepada anaknya setiap hari, tetapi yang lebih banyak berperan memberikan bimbingan adalah ibu. Pelajaran tentang shalat yang diberikan yaitu tentang cara wudhu, bacaan-bacaan dan gerakan-gerakan shalat (Ni'mah, 2016, p. 79).

Ketika anak-anak telah mencapai usia tujuh tahun, maka orang tua harus memerintahkannya untuk melaksanakan shalat, dan apabila pada usia sepuluh tahun anakanak tidak mau melaksanakan kewajiban tersebut, maka orang tua harus memukulnya sebagai bentuk hukuman atas kelalaian mereka itu (Ariyanti, L, 2020, p. 81). Setiap umat muslim diwajibkan untuk melaksanakan shalat lima waktu. Namun kenyataan yang terjadi saat sekarang ini, banyak anak anak sibuk bermain sampai lupa waktu. Mereka asik bermain dari pulang sekolah sampai sore hari, bahkan para orang tua pun tidak ada yang mencari anaknya untuk melaksanakan shalat, mereka hanya mencari anaknya untuk makan siang saja (Handayani, 2020, p. 3). Kesibukan orang tua dalam bekerja hingga membuat para orang tua hanya sedikit memberi pendidikan terhadap ibadah sholat anak. Pada umumnya pekerjaan orang tua adalah petani, pedagang dan pekerjaan lainnya yang banyak menyita waktu utuk bisa mendidik dan mengawasi pelaksanaan ibadah shalat anak di rumah (Yetti Anggraeni et al., 2019, p. 3).

Lain hal yang terjadi di Jorong Aceh Baru. Berdasarkan observasi awal pada tanggal 10 Oktober 2020 yang penulis lakukan terhadap anak-anak yang tinggal di Jorong Aceh Baru banyak anak anak yang sudah mengamalkan ibadah shalat wajib berjama'ah di mushala Nurul Yakin, yaitu mushala yang berada di Jorong Aceh Baru. Setelah peneliti melakukan prasurvei di lapangan secara langsung peneliti melihat dan mencermati sekarang ini ketika tiba shalat Ashar anak anak melaksanakan shalat di MDA tempat mereka belajar mengaji. 
Sedangkan saat tiba shalat Magrib, banyak terdapat juga anak anak mengikuti shalat berjama'ah di mushala Nurul Yakin.

Dari penuturan bapak Engki selaku wali jorong Aceh Baru diperoleh informasi bahwa salah satu cara yang dominan dilakukan oleh orang tua dalam membantu anaknya menanamkan ibadah shalat sejak dini adalah melalui pendidikan, yaitu memasukan anak ke dalam taman pendidikan Al-Quran atau yang biasa disebut MDA dan TPA. Berdasarkan latar belakang masalah tersebut, penulis tertarik untuk melakukan penelitian terhadap gejala tersebut dan penulis tuangkan dalam karya ilmiah berbentuk skripsi dengan judul peran orang tua dalam meningkatkan kesadaran ibadah shalat pada anak di Jorong Aceh Baru. Tujuan dari penelitian ini yaitu untuk mengetahui peran orang tua sebagai pendidik, sebagai motivator dan sebagai pengontrol dalam meningkatkan kesadaran ibadah shalat anak di Jorong Aceh Baru.

\section{Tinjauan Pustaka}

\section{Ibadah Sholat}

Ibadah Sholat dapat diartikan doa dan rahmat. Dan shalat adalah ibadah yang dimulai dari perkataan dan perbuatan tertentu yang dimulai dari takbir dan diakhiri dengan salam. Ibadah Sholat merupakan ibadah mahdlah yang termasuk kedalam kedalam salah satu rukun Islam yang lima. shalat merupakan ibadah yang sangat penting dibandingkan dengan ibadah-ibadah yang lain. Ibadah sholat dalam agama islam itu sangat penting sehingga dalam keadaan bagaimanapun, jika mukmin, musafir, waktu damai maupun perang, kewajiban shalat harus dilaksanakan (Hafsah, 2011, p. 41).

Menurut bahasa, shalat berarti doa dan rahmat, sedang menurut syara' berarti menghadapkan jiwa dan raga pada Allah, karena takwa hamba kepada Tuhan-nya, mengagungkan kebesarannya dengan khusuk dan ikhlas dalam bentuk perkataan dan perbuatan yang dimulai dengan takbir dan diakhiri dengan salam, menurut cara-cara dan syarat-syarat yang telah ditentukan (Pulungan, 2018, p. 9). Firman Allah SWT dalam surah Al Baqarah Ayat 238-239:

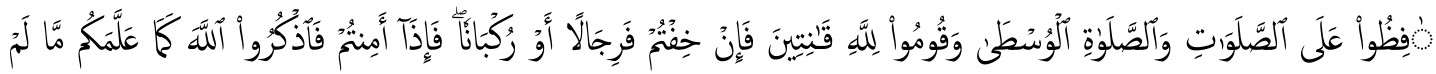

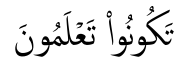

Artinya:

"Peliharalah semua shalat(mu), dan (peliharalah) shalat wusthaa. Berdirilah untuk Allah (dalam shalatmu) dengan khusyu'. Jika kamu dalam keadaan takut (bahaya), maka shalatlah sambil berjalan atau berkendaraan. Kemudian apabila kamu telah aman, maka sebutlah Allah (shalatlah), sebagaimana Allah telah mengajarkan kepada kamu apa yang belum kamu ketahui".

Ibadah sholat ada dua macam, yaitu sholat wajib atau fardhu dan sholat sunnah, sholat fardhu hukumnya wajib, sebagaimana firman Allah SWT:

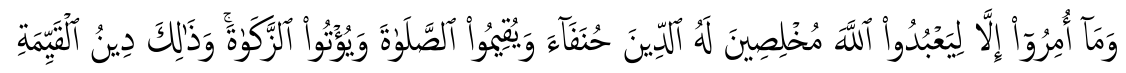

Artinya:

Padahal mereka tidak disuruh kecuali supaya menyembah Allah dengan memurnikan ketaatan kepadaNya dan dalam (menjalankan) agama dengan lurus, dan supaya mereka mendirikan shalat dan menunaikan zakat dan yang demikian itulah agama yang lurus. (Al Bayyinah : 5).

Sebagai sebuah kewajiban, perintah sholat tidak boleh di tinggalkan. Tidak ada satupun alasan yang dianggap sah oleh agama untuk boleh meninggalkan sholat, sholat harus tetap dikerjakan. Jika seseorang disibukkan dalam perjalanan, misalnya jika memang ia sangat sibuk, maka boleh baginya menjama' atau mengqashar sholat. 
Ade Amarta Yolanda dan Wirdati: Peran Orang Tua dalam Meningkatkan Kesadaran...

Bahkan betapapun parahnya sakit seseorang tetap saja ia diwajibkan melaksanakan sholat. Jika ada seseorang sakit hingga tidak mampu untuk melaksanakan sholat dengan berdiri, maka ia diperkenankan untuk sholat dengan cara duduk. Jika dirasa sakitnya agak berat hingga dengan cara sholat tidak mampu, maka baginya boleh sholat dengan cara berbaring. Jika dengan itu dirasa tidak mampu, tetap saja dia tak diperbolehkan meninggalkan kewajiban tersebut, dia harus tetap sholat meski hanya dengan cara isyarat (Shalih bin Fauzan, 2015, p. 113).

Dasar yang mewajibkan shalat sudah diatur dalam Al Quran, banyak sekali ayat yang menjelaskan diantaranya adalah:

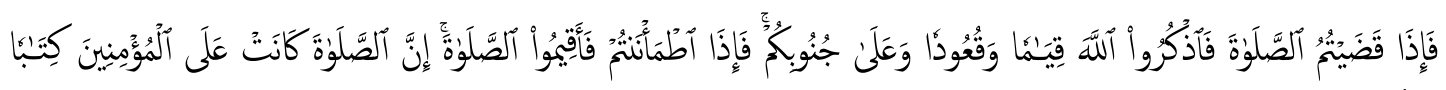

Artinya:

"Sesungguhnya shalat itu diwajibkan atas orang yang beriman, menurut waktu dan ketentuan"(An Nisa': 103).

Melaksanakan ibadah dalam sehari-hari mempunyai banyak hikmah dalam kehidupan kita. Adapun hikmah shalat sebagai berikut:

1) Shalat dapat menenteramkan hati.

2) Shalat dapat menyehatkan badan.

3) Shalat sumber kekuatan jiwa.

4) Shalat dapat menyehatkan badan.

5) Shalat sumber kekuatan jiwa.

6) Shalat sebagai penghapus dosa.

7) Amalan pertama dihisab pada hari kiamat.

8) Shalat penawar stress dan tekanan perasaan (Hafsah, 2011, p. 60).

\section{Orang Tua dan Anak}

Kamus Besar Bahasa Indonesia mengemukakan orang tua berasal dari kata "orang" yang berarti manusia (dalam arti khusus) dan "tua" yang berarti sudah lama hidup (KBBI, 2005, p. 801). Berdasarkan kutipan diatas dapat dipahami bahwa orang tua adalah orang atau manusia yang terlahir leebih dahulu. Menurut (Ginda, 2002, p. 211) orang tua adalah orang yang memiliki kewajiban memberi nafkah dan mendidik anak anaknya dalam sebuah keluarga. Jadi orang tua adalaah orang yang lebih dewasa atau orang yang lebih tua yang berperan memiliki tanggung jawab untuk memberi pendidikan kepada anak anaknya.

Sedangkan menurut (TB. Aat Syafaat at Al, 2008, p. 62) berpendapat bahwa orang tua adalah pendidik pertama dan utama dan dari orang tua juga anak mendapat pendidikan pertama kali. Orang tua merupakan pendidik utama dan pertama bagi anak-anak mereka, karena merekalah anak mula-mula menerima pendidikan. Dengan demikian bentuk pertama dari pendidikan terdapat kehidupan keluarga. Keluarga atau orang tua merupakan tempat pertama dan utama dalam membentuk konsep diri anak.

Orang tua dalam perfektif islam merupakan orang dewasa yang bertanggung jawab memberikan pertolongan kepada anaknya dalam perkembangan jasmani dan rohaninya, agar mencapai tingkat kedewasaannya serta mampu mandiri dalam menyelesaikan tugasnya sebagai hamba Allah. Dasar dasar pandangan hidup, sikap dan perilaku secara alami akan tertanam dalam diri anak melalui keteladanan dan pendidikan yang diberikan kepada anak oleh orang tuannya.

Pangkal ketentraman dan kedamaian hidup terletak dalam keluarga. Mengingat pentingnya hidup kelurga yang demikian, maka Islam memandang keluarga bukan hanya sebagai persekutuan hidup terkecil saja, melainkan lebih dari itu, yakni sebagai lembaga hidup manusia yang memberi peluang kepada para anggotanya untuk hidup celaka atau bahagia dunia dan akhirat.

Pertama-tama yang diperintahkan Allah kepada Nabi Muhammad dalam mengembangkan agama Islam adalah untuk mengajarkan agama itu kepada keluarganya, 
baru kemudian kepada masyarakat luas. Hal itu berarti di dalamnya terkandung makna bahwa keselamatan keluarga harus lebih dahulu mendapat perhatian atau harus didahulukan ketimbang keselamatan masyarakat. Karena keselamatan masyarakat pada hakikatnya bertumpu pada keselamatan keluarga. Firman Allah:

Artinya:

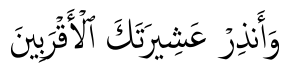

"Dan berilah peringatan kepada kerabat-kerabatmu yang terdekat" (QS. Asy-Syuara': 214)

Demikian pula Islam memerintahkan agar para orang tua berlaku sebagai kepala dan pemimpin dalam keluarganya serta berkewajiban untuk memelihara keluarganya dari api neraka, sebagaimana firman Allah:

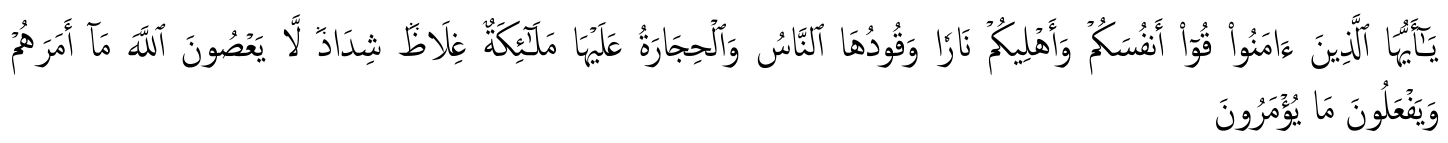

Artinya:

"Hai orang-orang yang beriman, peliharalah dirimu dan keluargamu dari api neraka yang bahan bakarnya adalah manusia dan batu; penjaganya malaikat-malaikat yang kasar, keras, dan tidak mendurhakai Allah terhadap apa yang diperintahkan-Nya kepada mereka dan selalu mengerjakan apa yang diperintahkan".(QS. At-Tahrim: 6)

a. Pengertian Anak

Anak adalah laksana kertas putih bersih yang di atasnya boleh dilukis apa saja menurut orang tua dan pendidik, atau laksana lilin yang lembut yang bisa dibentuk menurut keinginan siapa saja yang ingin membentuknya (Unarsa, 2002, p. 20). Dalam kamus besar bahasa indonesia anak diartikan sebagai keturunan kedua atau manusia yang masih kecil.

Menurut Dzakiyah Daradjat, anak adalah manusia yang dilahirkaan oleh seorang ibu, usia anak pada periode pertama kisaran 0-6 tahun, anak periode kedua berumur kisaran 612 tahun, masa awal remaja kisaran umur 13-16, remaja akhir kisaran 17-21 dan masa dewasa kisaran diatas 21 tahun (Daradjat, 1992, p. 109).

Menurut Melly Sulastri bahwa mana anak sekolah adalah periode berkembangnya antara umur 6-12 tahun yang memiliki tiga cara pokok yaitu :

1. Dorongan keluar dari rumahnya dan berbaur dengan teman sebaya.

2. Dorongan yang bersifat kejasmanian untuk memasuki dunia permainan dan dunia kerja yang menuntut untuk keterampilan.

3. Dorongan untuk memasuki dunia orang dewasa yaitu dunia konsep-konsep logika, simbol dan komunikasi dorongan mental (Melly Sulastri Rifa"I, 1993, p. 19).

Ada beberapa kewajiban yang harus diperhatikan dan dilakukan setelah kita mempunyai bayi/anak yaitu bersyukur kepada Allah SWT, beraqiqah, memberi nama yang baik, menikahkan, mengajarkan kewajiban untuk melaksanakan shalat (Hadiawati, 2017, p. 21)

Peran orang tua pada dasarnya sangat penting dalam kehidupan anak. Dari orang tua lah anak akan belajar dengan segala hal yang menyangkut tata kehidupan. Dari mulai hal yang kecil hingga besar, anak akan cenderung mencontoh kegiatan orang tua baik langsung ataupun tidak langsung. Dengan demikian, orang tua wajib menjalankan peran- peran sebagai orang tua itu sendiri. Peran orang tua yang sedang digaungkan pada saat ini adalah menyangkut tata kehidupan anak, yaitu menjauhkan dari sifat materialisme, pemanjaan dan paham kebebasan yang terlalu longgar kepada anak (Jamaluddin Didin, 2013, p. 145).

Sebagai orang pertama yang menjadi role model dari seorang anak, maka orang tua wajib memberikan contoh dan juga mendidik anaknya dengan baik dan benar yang nantinya akan menirukan apa yang dilakukan ayah ibunya. Dalam mendidik anak, pada dasarnya ada banyak peran dari orang tua, yang akan mempengaruhi pola pikir dan juga prilaku dari seorang anak. Ajaran Islam meletakkan dua landasan utama bagi permasalahan anak. Pertama, tentang kedudukan dan hak-hak anak. Kedua, tentang pembinaan sepanjang 
Ade Amarta Yolanda dan Wirdati: Peran Orang Tua dalam Meningkatkan Kesadaran...

pertumbuhannya. (Amin Munir Samsul, 2007, p. 16). Diatas kedua landasan inilah yang merupakan dambaan setiap orang tua muslim.

22)

Peran orang tua dalam mendidik anak, antara lain: (Amin Munir Samsul, 2007, pp. 21-

a) Mengajarkan kepada anak bahwa shalat merupakn tiang agama.

b) Ajarkan Tata Cara Shalat. Ajarkan anak anda untuk mengenal gerakan-gerakan shalat secara bertahap. Pada awalnya anda bisa mengajarkan bagaimana bertakbir, dan ajaklah si kecil untuk menirukannya. Proses pembelajaran bagi si kecil hendaknya dilakukan dengan suasana rileks dan penuh keceriaan, sehingga anak dapat menikmatinya. Tidak perlu memaksakan, tetapi biarkan anak berkembang secara bertahap.

c) Membina, hendaknya orangtua memberikan pemahaman bagaimana pentingnya shalat bagi umat islam. "Caranya dengan menjelaskan kepada sang anak bahwa shalat merupakan kewajiban bagi umat islam".

d) Menceritakan pahala serta azab yang diberikan allah apabila tidak melaksanakan shalat.

Dalam rangka mendidik anak terutama perihal ibadah shalat banyak cara yang bisa dilakukan oleh orang tua agar anaknya mau menunaikan ibadah shalat, mengajak keluarga untuk menunaikan shalat merupakan kewajiban dari setiap anggota keluarga. jika kedua orang tua telah rutin menjalankan kewajiban lima waktu, ditambah dengan shalat- shalat nafilah, maka ajakan shalat harus dilakukan oleh orang tua kepada anaknya meskipun anak tersebut masih berusia dini. Setidaknya kita sebagai orang tua harus membiasakan anak tersebut mendengar kata "shalat" dan melihat orang tuanya mengerjakan shalat.

Peran orang tua untuk memotivasi anak agar mau melaksanakan ibadah shalat di antaranya: (Amin Munir Samsul, 2007, pp. 27-29) Pertama, Beri Teladan yang baik dalam beribadah. Orang tua hendaknya memberikan keteladanan bagi anaknya dalam masalah menjaga shalatnya. Bagi ayah, biasakan untuk shalat di masjid, namun tak ada salahnya sebelum berangkat ke masjid, biasakan untuk berpamitan dengan si kecil. Adapun ibu, ia dapat mencontohkan secara langsung bagaimana shalat dilakukan, yaitu dengan cara meletakkan anak tidak jauh dari tempat shalat ibu dengan harapan anak akan melihat setiap gerakan ibunya. Keteladanan orang tua menjadi bekal utama bagi anak dalam meniru setiap tingkah laku orang-orang disekitarnya.

Kedua, Penyediaan Fasilitas. Fasilitas merupakan sarana dan prasarana pendukung terjadinya proses belajar. Oleh sebab itu motivasi yang tidak kalah pentingnya dalam mengubah pribadi anak adalah kelengkapan fasilitas belajar agama, kelengkapan fasilitas yang diberikan oleh orang tua akan menjadikan anak semakin giat dalam belajar agama dan memudahkan ia belajar agama dengan begitu kecakapan dalam belajar agama dan beribadah akan terwujud. Salah satunya dengan memberikan perlengkapan terwujud. Salah satunya dengan memberikan perlengkapan shalat dengan motif yang menarik. Namun demikian, hendaknya tidak memilih motif berupa gambar makhluk bernyawa, seperti manusia atau binatang.

Ketiga, Pemberian Hadiah Dan Pujian. hadiah dan pujian merupakan alat motivasi yang dapat menjadikan pedoman bagi anak untuk belajar lebih baik dan giat. Hadiah atau imbalan adalah merupakan suatu cara yang dipakai atau di gunakan oleh orang tua dalam mendukung sikap dan tindakan yang baik, yang telah ditunjukkan oleh anak. Hadiah yang dimaksud disini adalah yang berupa barang, barang ini dapat terdiri dari alat-alat keperluan mengaji seperti kopyah, kitab, buku pelajaran dan sebagainya.

Peran orang tua dalam mengontrol anak:

a) Sebagai pengawas, kewajiban orang tua adalah melihat dan mengawasi sikap dan perilaku anak agar tidak keluar jauh dari jati dirinya, terutama dari pengaruh lingkungan baik dari lingkungan keluarga, sekolah maupun lingkungan masyarakat.

b) Mengontrol anak-anak waktu shalat, memperhatikan wudhunya, mengingatkan bacaanya, serta mengingatkan gerakannya.

c) Memahami anak dengan segala aktifitasnya, termasuk pergaulannya. 


\section{Metode}

Penelitian ini menggunakan jenis penelitian field research (penelitian lapangan). Penelitian yang bertujuan untuk mengetahui bagaimana cara orang tua dalam meningkatkan kesadaran ibadah shalat anak. Ide pentingnya adalah bahwa peneliti berangkat ke lapangan untuk mengadakan suatu penelitian dalam suatu keadaan (Hardani et al., 2002, p. 51). Penelitian ini menggunakan metode kualitatif deskriptif. Dengan pendekatan kualitatif ini peneliti mencoba menggambarkan peran orang tua dalam meningkatkan kesadaran ibadah shalat fardhu pada anak dengan menggunakan logika-logika serta teori-teori yang sesuai dengan lapangan. Alasan peneliti menggunakan metode ini adalah peneliti melihat kenyataan yang ada di lapangan dengan melihat prilaku-prilaku anak yang di amati. Karena sudah banyak anak anak yang taat beribadah pada jorong tersebut.

Penelitian ini dilakukan di Jorong Aceh Baru, Kenagarian Batu Palano, Kecamatan Sungaipua, Kabupaten Agam. Dalam penelitian ini menentukan informan dengan menggunakan purposive sampling yaitu teknik pengambilan sampel sumber data dengan pertimbangan tertentu. Adapun yang dijadikan informan dalam penelitian ini adalah orang tua yang memiliki anak berumur kisaran 6-12 tahun. Penulis melakukan observasi langsung di lingkungan Jorong Aceh Baru untuk mendapatkan data yang berkaitan dengan penelitian. Instrumen penelitian yang penulis gunakan adalah: handphone (untuk alat rekam serta camera sebagai bukti dokumentasi). Dalam penelitian ini teknik pengumpulan data yang digunakan adalah observasi, wawancara, dan dokumentasi. Teknik penganalisisan data yang digunakan yaitu reduksi data, penyajian data, penarikan kesimpulan dan verifikasi. Teknik pengabsahan yang digunakan dalam penelitian ini yaitu dengan menggunakan teknik triangulasi sumber. Teknik triangulasi sumber yaitu: mengecek data yang telah diperoleh melalui beberapa sumber.

\section{Hasil dan Pembahasan}

Shalat bagian dari rukun islam dan menjadi tiang agama yang mewajibkan orang tua untuk memberikan pendidikan kepada anaknya sejak dini. Itu bertujuan untuk memberikan bekal pengalaman keagamaan kepada anak sejak dini, sehingga anak sudah memiliki bekal keagamaan saat masuk sekolah nanti. Berkaitkan dengan pengalaman orang tua dalam meningkatkan kesadaran ibadah shalat anak di Jorong Aceh Baru.

Berhasil atau gagalnya proses pendidikan ibadah shalat dalam lingkungan keluarga sepenuhnya tergantung pada peranan orang tua dalam memahami dan menciptakan hubungan yang baik dengan anak dengan keluarga yang berdasarkan nilai Al Quran dan sunnah dalam menerapkan pendidikan shalat. Orang tua sebagai pendidik utama bagi anak diharapkan mampu menciptakan pendidikan yang kondusif sehingga anak dapat menjalani kehidupan dengan positif. Setiap orang tua tentunya mempunyai metode yang berbeda beda dalam membeikan bimbingan pada anak terutama membimbing ibadah shalat anaknya. Penulis melakukan wawancara dengan beberapa orang tua dengan hasil:

Tema pertama yaitu Peran orang tua sebagai pendidik dalaam meningkatkan kesadaran ibadah shalat anak di Jorong Aceh Baru. Cara yang dilakukan orang tua dalam mendidik anaknya dengan memasukan si anak ke Mda agar mendapatkan pendidikan lebih, menanyakan kembali apa saja yang dipelajari oleh anak mereka saat di sekolah dan mengulang atau mengajarkan kembali bacaan-bacaan yang tidak dimengerti oleh anak. Orang tua juga mengajari anak dengan cara mengulang kembali bacaan-bacaan shalat saat duduk bersama, mengajak anak untuk melaksanakan shalat bersama. Memberikan pengarahan dan kesadaran tentang pentingnya beribadah serta menceritakan azab dan pahala bagi orang yang tidak mau melaksanakan shalat.

Tabel 1. Petikan Wawancara Tema Pertama

\begin{tabular}{|l|c|l|}
\hline Tema & \multicolumn{1}{c}{ Informan } & Petikan Wawancara \\
\hline $\begin{array}{l}\text { Peran orang } \\
\text { tua sebagai }\end{array}$ & Welly & $\begin{array}{l}\text { Kami memberikan pendidikan kepada anak kami secara } \\
\text { bergantian, saya dan istri mengajarkan bacaan shalat }\end{array}$ \\
\hline
\end{tabular}


Ade Amarta Yolanda dan Wirdati: Peran Orang Tua dalam Meningkatkan Kesadaran...

\begin{tabular}{|c|c|c|}
\hline \multirow{7}{*}{$\begin{array}{l}\text { pendidik } \\
\text { dalam } \\
\text { meningkatkan } \\
\text { kesadaran } \\
\text { ibadah shalat } \\
\text { anak di Jorong } \\
\text { Aceh Baru }\end{array}$} & & $\begin{array}{l}\text { pada anak, sejak umur } 5 \text { tahun anak sudah kami ajarkan } \\
\text { gerakan shalat jadi pas di tk anak sudah memiliki } \\
\text { pengetahuan tentang tata cara shalat. Kami juga } \\
\text { menceritakan azab bagi orang yang tidak melaksanakan } \\
\text { shalat. }\end{array}$ \\
\hline & Dewi & $\begin{array}{l}\text { saya selalu mengajarkan bacaan shalat pada anak saya, } \\
\text { karena bapaknya rasyid sibuk bekerja jadi saya yang } \\
\text { sering di rumah mengajarkan rasyid dan adiknya gerakan } \\
\text { shalat, ayat ayat pendek. Kami juga memasukan rasyid ke } \\
\text { Mda untuk belajar agama, jadi dia lebih banyak mendapat } \\
\text { pelajaran tentang agama. }\end{array}$ \\
\hline & Elka & $\begin{array}{l}\text { Anak saya sudah belajar tentang shalat di sd dalam } \\
\text { pembelajaran agama islam dan kami juga memasukannya } \\
\text { ke Mda, jadi kalo di rumah saya sering meminta anak } \\
\text { untuk mengulang bacaan shalat. Jika anak tidak mau } \\
\text { melaksanakan shalat saya menasehati dengan cara } \\
\text { mencaritakan pahala bagi orang yang melaksanakan } \\
\text { shalat. }\end{array}$ \\
\hline & Iyam & $\begin{array}{l}\text { Anak saya belajar tata cara shalat di Mda, tetapi kalo di } \\
\text { rumah saya bertanya apa saja yang dipelajarinya. Jika } \\
\text { anak saya tidak mengerti saya mengulang mengajarinya. }\end{array}$ \\
\hline & Parida & $\begin{array}{l}\text { Kalau saya sambil mengajarkan anak saya shalat, saya } \\
\text { juga memasukan anak saya belajar di Mda. Anak saya } \\
\text { sangat bersemangat untuk shalat karena teman temannya } \\
\text { pun kebanyakan melaksanakan shalat juga }\end{array}$ \\
\hline & Yarni & $\begin{array}{l}\text { Saya dan suami mulai mengajari anak gerakan shalat } \\
\text { anak sejak umur } 4 \text { tahun, saya selalu mengajak serta anak } \\
\text { untuk shalat saat kami melaksanakan shalat bersama agar } \\
\text { anak bisa melihat dan menirukan gerakan shalat kami. } \\
\text { Saat anak sudah masuk TK dia mulai di ajarkan bacaan- } \\
\text { bacaan shalat seperti Al-Fatihah, jadi di rumah kami } \\
\text { mengulang mengajarinya }\end{array}$ \\
\hline & Sarinah & $\begin{array}{l}\text { Kami memulai mengajari anak sejak kecil, kira-kira umur } \\
\text { 3,5 tahun. Kami memulai mengajarinya gerakan shalat } \\
\text { dengan mengajaknya melihat kami shalat dan } \\
\text { memintanya untuk mengikuti. Kami juga tidak lupa } \\
\text { menceritakan kewajiban kita sebagai umat islam untuk } \\
\text { melaksanakan shalat. Dan Alhamdulillah sampai saat ini } \\
\text { anak saya tidak pernah meninggalkan shalat karena sudah } \\
\text { mendapat pendidikan sejak kecil }\end{array}$ \\
\hline
\end{tabular}

Orang tua mengajak anak melaksanakan shalat bersama di masjid dan di rumah. Orang tua berharap dari kecil anaknya sudah terbiasa melaksanakan shalat entah khusuk atau tidak yang penting anaknya terbiasa melaksanakan shalat sampai besar kelak. Orang tua biasa mengajak anak shalat di masjid atau di rumah. Hal ini sejalan dengan dengan perkataan ibu Farida dan bapak Iyam yaitu peran orang tua dalam dengan cara mengajak anak untuk shalat berjamaah di masjid atau mushala.

Mengajarkan tata cara shalat. Para orang tua akan selalu berusaha mendidik dan mengajari anaknya agar menjadi orang yang pandai, apalagi soal agama. Para orang tua di Jorong Aceh Baru mengajarkan anaknya bacaan dan gerakan shalat. Seperti yang dijelaskan oleh bapak Welly, beliau memberikan pendidikan kepada anak secara bergantian dengan istri. Mereka mulai mengajari anak bacaan shalat saat anak mulai umur 5 tahun. 
Hal serupa juga dilakukan oleh ibu dewi beliau selalu mengajarkan anaknya bacaan shalat. Walaupun mereka sibuk bekerja tapi mereka selalu mencari kesempatan untuk mengajari anaknya gerakan shalat, ayat-ayat pendek dan bacaan shalat lainnya. Umumnya para orang tua di Jorong Aceh Baru mengajarkan anak mereka bacaan shalat.

Menasehati dan menyadarkan anak bahwa shalat merupakan kewajiban yang tidak dapat ditinggalkan. Orang tua menyadarkan anaknya secara pelan-pelan. Para orang tua melakukan segala cara agar anak mereka tidak meninggalkan shalat. Seperti yang dilakukan oleh keluarga buk Sarinah, sejak anak berumur 3,5 tahun beliau sering mengatakan kepada anaknya bahwa shalat adalah kewajiban umat islam. Dengan mengatakan shalat merupakan kewajiban dan didampingi ayat-ayat yang membahas kewajiban melaksanakan shalat otomatis anak akan cepat paham.

Memberikan nasehat pada anak tidak membutuhkan biaya dalam mendidik anak, karena cukup dengan diberikan arahan dan bimbingan supaya anak mengerti. Banyak orang tua yang memberikan nasehat dengan penuh kasih sayang, menggunakan bahasa yang baik dan lemah lembut. Para orang tua terkadang menasehati anak saat mau tidur atau sedang duduk bersama. Hal ini dilakukan karena biasanya akan saat akan tidur kondisi anak sedang stabil atau tidak dalam keadaan emosi jadi akan lebih memudahkan orang tua untuk menasehati anak.

Menceritakan pahala dan azab bagi yang tidak melaksanakan shalat. Dengan menceritakan azab bagi yang tidak melaksanakan shalat pada anak otomatis anak akan takut jika meninggalkan shalat. Hal ini dilakukan oleh buk Elka, beliau menceritakan azab bagi orang yang tidak melaksanakan shalat pada anaknya jika si anak malas melaksanakan shalat. Orang tua menceritakan azab kepada anak agar anak takut jika meninggalkan shalat. Hal ini cukup ampuh membuat anak takut meninggalkan shalat. Ada juga orang tua yang menceritakan pahala bagi orang yang melaksanakan shalat agar anaknya bersemangat untuk melaksanakan shalat.

Memasukan anak ke sekolah agama, di Jorong Aceh Baru ada hal menarik yang penulis temukan, para orang tua memasukan anaknya ke MDA dan TPA, maksutnya para orang tua memasukan anaknya ke sekolah agama agar anak mendapat pendidikan agama lebih banyak. Umumnya para orang tua memasukan anaknya ke sekolah agama karena mereka tidak bisa memberikan pendidikan lebih mengenai agama kepada anak karena keterbatasan pendidikan dan kondisi.

Hal paling utama yang membuat orang tua memasukan anak ke MDA karena orang tua di Jorong Aceh Baru sibuk bekerja. Mayoritas pekerjaan orang tua di Jorong Aceh Baru adalah bertani, jadi mereka tidak memiliki waktu lebih untuk mengajarkan anaknya. Hal ini sejalan dengan perkataan buk Dewi beliau mengatakan saya selalu sibuk bekerja saat siang hari jadi saya memasukan anak ke MDA agar dia mendapatkan nilai agama lebih.

Tema kedua yaitu Peran orang tua dalam memberikan motivasi kepada anak dalam melaksanakan shalat juga sangat penting. Maka penulis sudah melakukan penelitian dengan hasil :

\section{Tabel 2. Petikan Wawancara Tema Kedua}

\begin{tabular}{|c|c|c|}
\hline Tema & fforman & Petikan Wawancara \\
\hline $\begin{array}{l}\text { Pera } \\
\text { Tua : } \\
\text { Moti } \\
\text { dala } \\
\text { Meni }\end{array}$ & Welly & $\begin{array}{l}\text { saya selalu memuji anak saya saat selesai melaksanakan } \\
\text { shalat. Saya sangat bangga kepada anak saya karena } \\
\text { shalaatnya sudah lengkap saat menduduki kelas } 3 \text { Sd. } \\
\text { Bahkan saya memberikannya uang jajan lebih setiap } \\
\text { sebulan sekali karena shalatnya lengkap }\end{array}$ \\
\hline $\begin{array}{l}\text { Kesadaran } \\
\text { lbadah Shalat } \\
\text { Anak di }\end{array}$ & Fira & $\begin{array}{l}\text { Saya dan suami akan berusaha mencukupi semua } \\
\text { fasilitas beribadah yang dibutuhkan anak saya agar dia } \\
\text { memiliki semangat yang tinggi untuk beribadah kepada } \\
\text { Allah SWT }\end{array}$ \\
\hline Baru & Erni & Jika anak melaksanakan shalat tepat waktu kami selalu \\
\hline
\end{tabular}




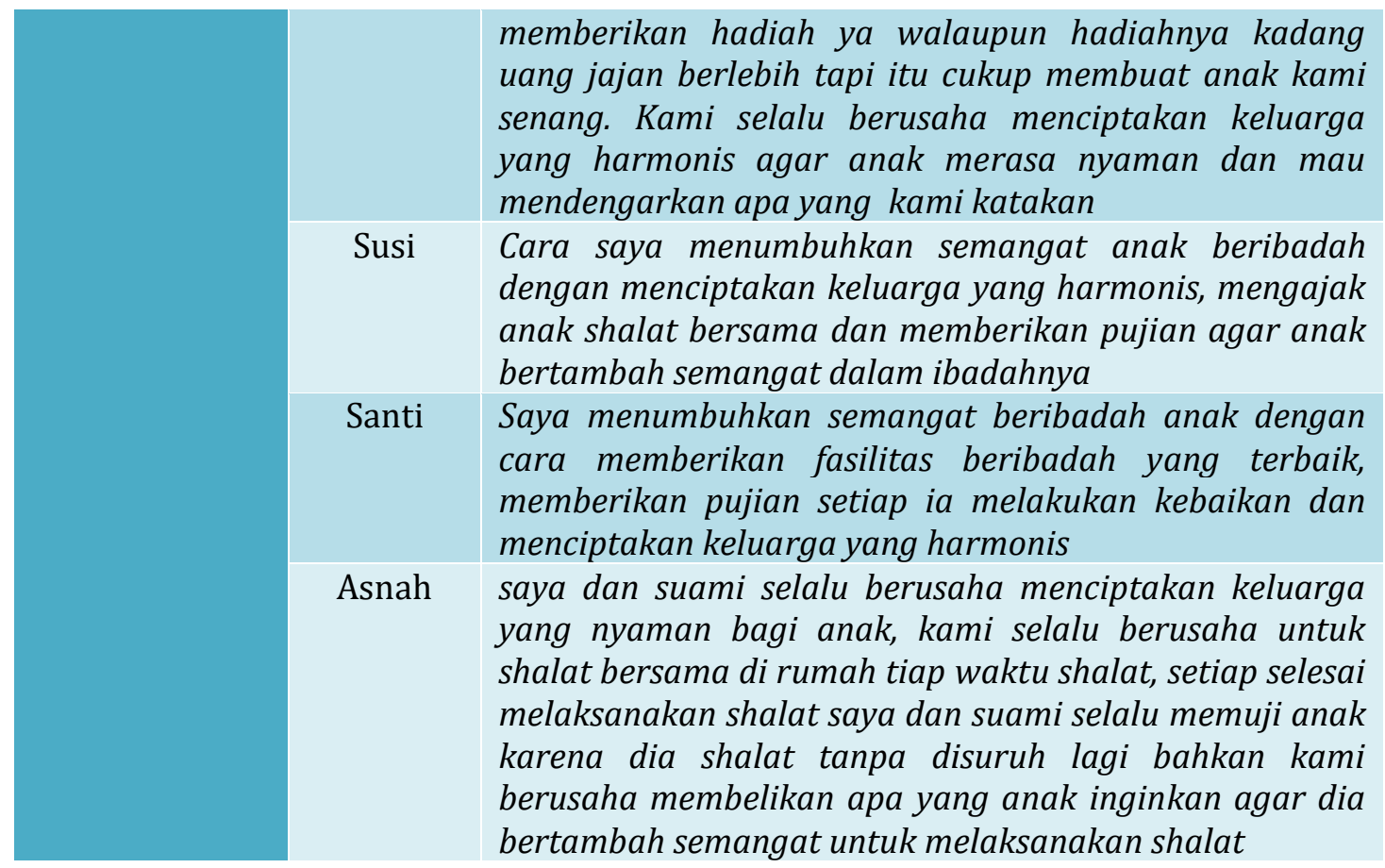

Dari hasil wawancara diatas dapat diketahui bahwa peran orang tua sebagai memotivator dalam meningkatkan kesadaran ibadah shalat anak di Jorong Aceh Baru yaitu dengan orang tua di Jorong Aceh Baru berusaha menciptakan keluarga yang harmonis agar anak mau mendengarkan semua kata-kata orang tuanya.

Para orang tua memberikan fasilitas yang lengkap kepada anak agar anak bersemangat dalam melaksanakan ibadah. Dan mereka juga memberikan hadiah agar anak anak mau melaksanakan shalat tepat waktu, hal terkecil yang lakukan orang tua dalam memotivasi anak yaitu dengan memberikan pujian karena anak mereka rajin dalam melaksanakan shalat.

a. Memberikan keteladanan yang baik. Para orang tua biasanya memberikan contoh yang baik agar anak dapat menirukan hal-hal baik. Hal ini sejalan dengan perkataan buk Fira beliau selalu berusaha memperlihatkan hal-hal positif yang dapat membentuk karakter anaknya. Misalnya melaksanakan shalat di depan anak, shalat bersama dan mengaji selesai melaksanakan shalat magrib. Dengan memberikan keteladan yang baik akan memudahkan orang tua untuk memotivasi anak berbuat kebaikan juga. Orang tua sering shalat di depan anak maka anak akan tergerak hatinya untuk melaksanakan shalat juga.

b. Menyediakan fasilitas yang lengkap. Fasilitas yang dimaksut disini adalah fasilitas yang dapat menunjang kegiatan anak untuk melaksanakan shalat. Misalnya membelikan mukena, alat-alat untuk mengaji dan buku-buku bacaan shalat. Hal ini sejalan dengan ibuk Santi, salah satu cara yang dilakukan ibu santi yaitu memberikan fasilitas beribadah terbaik untuk menumbuhkan semangat beribadah anak.

c. Pemberian hadiah dan pujian. Ketika anak pandai melaksanakan ibadah shalat dalam kehidupan sehari-hari bahkan sudah menjadikan shalat sebagai kewajiban mereka terhadap Allah tentu itu menjadi kebanggaan bagi orang tua. Banyak hal yang dilakukan orang tua agar anak mempertahankan kebiasaan baiknya tersebut. Pemberian hadiah dan pujian merupakan alat motivasi yang dapat menjadi pedoman bagi anak untuk belajar lebih giat lagi. Hal ini sejalan dengan yang dilakukan ibuk Erni, beliau mengatakan jika anaknya melaksanakan shalat tepat waktu mereka selalu memberikan hadiah walaupun hadiahnya hanya memberikan uang jajan lebih hal itu setidaknya dapat menumbuhkan semangat anak untuk melaksanakan shalat lebih rajin lagi. Selain memberikan hadiah bisa juga memotivasi anak dengan cara memberikan pujian. Memberikan pujian tidak perlu mengeluarkan biaya, hanya bermodalan kata-kata manis akan membuat anak tersanjung. 
Hal ini sejalan dengan yang dilakukan buk Asnah beliau memberikan pujian kepada anak setiap anaknya selesai melaksanakan shalat tanpa disuruh dan selalu melaksanakan shalat tepat waktu.

d. Menciptakan keluarga yang harmonis. Temuan lainnya yang peneliti dapatkan yaitu setiap keluarga berusaha mmenciptakan keluarga yang harmonis. Keluarga yang harmonis tentu saja menjadi dambaan semua orang. Jika seorang anak terlahir dalam keluarga yang harmonis sudah pasti orang tua tidak akan susah lagi untuk mengajarkan anak dalam beribadah. Anak akan nyaman dalam subuah keluarga yang harmonis. Hal ini dilakukan oleh buk Asnah, beliau dan suami berusaha menciptakan keluarga yang harmonis bagi anak mereka. Hal serupa juga dilakukan oleh buk Santi, beliau mengatakan untuk menumbuhkan semangat beribadah dan agar anak mereka mau mendengarkan apa yang mereka katakan, dia dan suami berushala menciptakan keluarga yang harmonis untuk anaknya.

Tema ketiga yaitu Peran Orang Tua sebagai Pengawas dalam Meningkatkan Kesadaran Ibadah Shalat Anak di Jorong Aceh Baru

Tabel 3. Petikan Wawancara Tema Ketiga

\begin{tabular}{|c|c|c|}
\hline Tema & Informan & Petikan Wawancara \\
\hline \multirow{7}{*}{$\begin{array}{l}\text { Peran Orang } \\
\text { Tua sebagai } \\
\text { Pengawas } \\
\text { dalam } \\
\text { Meningkatkan } \\
\text { Kesadaran } \\
\text { Ibadah Shalat } \\
\text { Anak di } \\
\text { Jorong Aceh } \\
\text { Baru }\end{array}$} & Ilham & $\begin{array}{l}\text { cara saya dan istri dalam mengawasi anak yaitu selalu } \\
\text { menanyakan pada anak dia sudah melaksanakan shalat } \\
\text { atau belum }\end{array}$ \\
\hline & Nina & $\begin{array}{l}\text { Kalo saya selalu memperhatikan dengan siapa anak saya } \\
\text { bermain, dengan orang yang rajin shalatkah atau dengan } \\
\text { anak yang malas melaksanakan shalat. Jika dia bermain } \\
\text { dengan anakyang rajin shalat maka saya tidak perlu takut } \\
\text { anak saya akan meninggalkan shalat karena sudah pasti } \\
\text { mereka akan melaksanakan shalat bersama atau saling } \\
\text { mengingatkan }\end{array}$ \\
\hline & Aswat & $\begin{array}{l}\text { Saya selalu menanyakan kepada guru ngaji yuna } \\
\text { bagaimana bacaan shalat yuna dan apakah anak saya } \\
\text { selalu melaksanakan shalat jika ditanya oleh gurunya } \\
\text { tersebut, kami juga memperhatikan pergaulan yuna } \\
\text { dengan teman-temannya, ya kalo dapat yuna bermain } \\
\text { dengan anak yang rajin shalat juga agar mereka saling } \\
\text { mengingatkan }\end{array}$ \\
\hline & Desi & $\begin{array}{l}\text { saat pulang bekerja saya selalu menanyakan pada anak } \\
\text { dia sudah melaksanakan shalat atau belum. Dan jika kami } \\
\text { sama-sama di rumah saya selalu meminta anak untuk } \\
\text { melaksanakan shalatjika waktunya telah tiba }\end{array}$ \\
\hline & Yossi & $\begin{array}{l}\text { Selain mengajari anak tentunya kami juga memberikan } \\
\text { pengawasan apa saja yang dilakukan oleh anak misalnya } \\
\text { dengan siapa dia bermain, apa saja yang dilihatnya saat } \\
\text { menonton televisi, karena pengaruh dari luar sangat } \\
\text { berdampakpada pendidikan agama anak }\end{array}$ \\
\hline & Kartini & $\begin{array}{l}\text { kami selalu berusaha memberikan yang terbaik untuk } \\
\text { dika, kami selalu bertanya apakah dika sudah } \\
\text { melaksanakan shalat bahkan kami seing mengajak dika } \\
\text { untuk melaksanakan shalat bersama }\end{array}$ \\
\hline & Nasrul & $\begin{array}{l}\text { Anak saya Alhamdulillah selalu melaksanakan shalat, saya } \\
\text { dan istri selalu mengontrol bacaan shalat andi. Kami juga } \\
\text { mengawasi anak saat bermain handphone dan menonton }\end{array}$ \\
\hline
\end{tabular}




\section{televisi agar dia tidak melihat sesuatu yang tidak} diinginkan

Dari hasil wawancara di atas di dapat informasi bahwa peran orang tua sebagai pengontrol dalam meningkatkan kesadaran ibadah shalaat anak dilakukan dengan cara para orang tua selalu menanyakan apakah anak mereka telah melaksanakan shalat, mereka tidak lupa pula selalu mengingatkan anaknya untuk melaksanakan shalat tepat waktu. Para orang tua juga selalu mengontrol dengan siapa anak mereka bergaul bahkan mengontrol anak mereka saat menonton televisi dan bermain handphone. Orang tua juga selalu bertanya bagaimana keadaan bacaan shalat anak kepada guru di sekolah.

1. Mengingatkan anak untuk melaksanakan shalat. Walaupun anak sudah melaksanakan shalat, orang tua tidak bisa lepas tengan untuk mengontrol shalat anak. Orang tua hari selalu mengingatkan anak untuk melaksanakan shalat. Anak jika dibiarkan tanpa pengawasan orang tua akan menjadi lalai bahkan bisa saja tidak melaksanakan shalat.

Hal ini sejalan dengan yang dilakukan oleh pak Ilham, beliau mengatakan bahwa dia selalu mengawasi anaknya saat shalat dan selalu mengingatkan anaknya untuk melaksanakan shalat. Jika anak dibiarkan atau tidak diingatkan maka anak akan menyangka orang tuanya tidak peduli dengan ibadah shalatnya.

2. Mengontrol pergaulan anak. Salah satu hal yang akan merusak karakter seorang anak yaitu pergaulan. Jika anak mendapat teman yang rajin melaksanakan shalat orang tua tidak perlu khawatir karna sudah pasti mereka akaan saling mengingatkan jika waktu shalat tiba. Tapi jika anak mendapatkan teman yang tidak melaksanakan shalat orang tua perlu was-was agar anak tidak terbawa sifat malas temannya tersebut.

Hal ini sejalan dengan yang dilakukan oleh Aswat, beliau mengatakan bahwa dia selalu memperhatikan pergaulan yuna dengan teman sebayanya. Jika yuna bergaul dengan teman yang rajin shalat, pak Aswat tidak perlu khawatir karena mereka akan saling mengingatkan jika waktu shalat tiba.

3. Selalu bertanya pada guru. Maksutnya di sini adalah orang tua harus sering bertanya kepada guru bagaimana perkembangan bacaan shalat anak. Bertanya apakah anak selalu melaksanakan shalat saat berada di sekolah. Hal ini sejalan dengan yang dilakukan pak Aswat, beliau datang ke sekolah untuk menanyakan bagaimana perkembangaan ibadah yuna sambil membayarkan uang sekolah yuna. Walaupun orang tua sudah memasukan anaknya ke sekolah agama, MDA dan TPA orang tua harus selalu menanyakan perubahan yang di dapat anaknya selama belajar di sekolah tersebut. Jangan sampai antara oraang tua dengan guru terputus komunikasi. Hal ini untuk mempermudah proses pendidikan anak.

\section{Simpulan}

Berdasarkan hasil penelitian yang telah peneliti lakukan, maka ada beberapa kesimpulan yang dapat disimpulkan yaitu pertama, peran orang tua sebagai pendidik dalam meningkatkan kesadaran ibadah shalat fardhu di Jorong Aceh Baru dilakukan dengan cara memasukan anak ke MDA/TPA, mengulang kembali apa yang dipelajari anak, menceritakan pahala bagi orang yang melaksanakan shalat, mengajak anak untuk melaksanakan shalat di masjid dan di rumah, memberikan pengarahan dan pemahaman pada anak tentang pentingnya beribadah, terkadang sambil santai-santai mengajarkan anak tentang bacaan dan gerakan shalat. Kedua, peran orang tua sebagai motivator dalam meningkatkan kesadaran ibadah shalat fardhu di Jorong Aceh Baru dilakukan dengan cara memberikan hadiah kepada anak jika melaksanakan shalat, memberikan pujian kepada anak, memberikan fasilitas beribadah yang lengkap, menciptakan keluarga yang harmonis. Ketiga, peran orang tua sebagai pengawas dalam meningkatkan kesadaran ibadah shalat fardhu di Jorong Aceh Baru dilakukan dengan cara selalu bertanya kepada anak apakah sudah melaksanakan shalat atau belum, selalu mengingatkan untuk melaksanakan shalat tepat waktu, mengawasi pergaulan anak, selalu bertanya kepada guru bagaimana ibadah si anak, memantau dan menemani anak saat menonton televisi dan bermain handphone. 


\section{Referensi}

Amin Munir Samsul. (2007). Menyiapkan Masa Depan Anak Secara Islami. Amzah.

Ariyanti, L, F. (2020). Strategi Orang Tua Millenial Dalam Menanamkan Kesadaran Menjalankan Shalat Lima Waktu. Jurnal Ilmu Pendidikan.

Daradjat, Z. (1992). Ilmu Pendidikan Islam. Bumi Aksara.

Ginda. (2002). Profil Orang Tua Sebagai Pendidik Dalam Perspektif Alqur'an. In Jurnal Sosial Budaya (Vol. 8, Issue 02).

Hadiawati, L. (2017). Pembinaan Keagamaan Sebagai Upaya Meningkatkan Kesadaran Siswa Melaksanakan Ibadah Shalat (Penelitian Di kelas X dan XI SMK Plus QurrotaAyun Kecamatan Samarang Kabupaten Garut. "Jurnal Pendidikan UNIGA, 18-25.

Hafsah. (2011). Fiqih. Citapustaka Media Perintis.

Handayani, S. (2020). Lima Waktu Anak di Desa Gunung Sugih Kecil.

Hardani, H., Medica, P., Husada, F., Andriani, H., Sukmana, D. J., Mada, U. G., \& Fardani, R. (2002). Buku Metode Penelitian Kualitatif \& Kuantitatif (Issue April).

Jamaal 'Abdul Rahman. (2005). Tahapan mendidik Anak Teladan Rasulullah. Irsyad Baitul Salam.

Jamaluddin Didin. (2013). Paradigma Pendidikan Anak Dalam Islam. Pustaka Setia.

Melly Sulastri Rifa"I. (1993). Bimbingan Perawatan Anak. Rieke Cipta.

Ndibo, Y. La, \& Baru, W. (2020). Peranan Orangtua dalam Membina Kedisiplinan Anak. 1(2), $75-84$.

Ni'mah. (2016). Peranan Orang Tua Dalam Membimbing Anak Untuk Melaksanakan Sholat Lima Waktu Di Lingkungan Pasar Kahayan Palangka Raya (Studi Terhadap Lima Kepala Keluarga yang Berprofesi sebagai Pedagang). 1-80.

Pulungan, E. N. (2018). Peranan Orang Tua Dalam Mengajarkan Pendidikan Shalat Pada Anak Sejak Usia Dini. Jurnal Raudhah.

Ridwan Hasan. (2009). Fiqh Ibadah. Pustaka Setia.

Shalih bin Fauzan. (2015). Ringkasan Fiqih Lengkap. PT Darul Falah.

TB. Aat Syafaat at Al. (2008). Peranan Pendidikan Agama Islam Dalam Mencegah Kenakalan Remaja. Jakarta Pres.

Unarsa, S. D. (2002). Psikologi Untuk Membimbing. PT . BPK Gunung.

Yetti Anggraeni, T. 151485, Armida, A., \& Syaifullah, M. (2019). Upaya Orang Tua dalam Mendidik Anak Sholat Wajib di Desa Sumber Sari Kecamatan Tungkal Jaya Kabupaten Musi Banyuasin. http://repository.uinjambi.ac.id/id/eprint/2442 